\title{
Controlled Self-Assembly of Carbohydrate Conjugate Rod- Coil Amphiphiles for Supramolecular Multivalent Ligands
}

\author{
Byung-Sun Kim, Dong-Je Hong, Jinyoung Bae and Myongsoo Lee* \\ ${ }^{\dagger}$ Center for Supramolecular Nano-Assembly and Department of Chemistry, \\ Yonsei University, Seoul 120-749, Korea
}

\section{Supporting Information}

Scheme 1. Synthesis of molecules 1 and 2.

Scheme 2. Synthesis of molecule $2 \mathbf{a}$.

Scheme 3. Synthesis of molecule 3.

Figure S1. Absorbance intensity of Nile Red at $550 \mathrm{~nm}$ as a function of the concentration of $\mathbf{1 - 3}$ solutions in water.

Experimental procedures for HIA, DLS and TEM.

"To whom all correspondence should be addressed.

e-mail : mslee@yonsei.ac.kr 
Materials. Benzoyl chloride, 4-bromo-4'-hydroxylbiphenyl, 1,8-diazabicyclo[5,4,0]-undec-7-ene, mercury(II) cyanide (99\%), p-toluene-sulfonyl chloride (98\%), trichloroacetonitrile (98\%), trimethylsilyl triflate from TCI were used as received. 3-chloro-2-chloromethyl-1-propene (99 \%), 3,4dihydro-2H-pyran (97\%), dimethylaminopyridine, D-(+)-galactose, D-(+)-mannose, tri(ethylene glycol), poly(ethylene glycol) $\left(\mathrm{M}_{\mathrm{W}}=600,900\right), n$-butyl lithium (1.6 M solution in $n$-hexane), triisopropyl borate, tetrakis(triphenylphosphine)palladium(0) (99\%), DOWEX MAC-3 ION exchange resin (all from Aldrich) were used as received. Concanavalin A (Con A) was purchased from Vector Laboratories, Inc. Fresh whole white rabbit blood was obtained from Department of physiology, College of Medicine, Yonsei University. Unless otherwise indicated, all starting materials and the conventional reagents were obtained from commercial suppliers (Aldrich, Lancaster, TCI, etc.). All atmosphere sensitive reactions were done under nitrogen. Flash column chromatography was carried out with Silica Gel 60 (230-400 mesh) from EM Science. 1-Bromo 2,3,4,6-tetra-O-acetyl-mannopyranoside, tosylated poly(ethylene glycol) and 4-biphenyl boronic acid were synthesized according to literatures. ${ }^{4,5}$

Techniques. ${ }^{1} \mathrm{H}$ and ${ }^{13} \mathrm{C}$ NMR spectra were recorded from $\mathrm{CDCl}_{3}$ or DMSO solutions on a Bruker AM 250 spectrometer. The purity of the products was checked by thin layer chromatography (TLC; Merck, silica gel 60). Microanalysis was performed with a Perkin Elmer 240 elemental analyzer at Organic Chemistry Research Center, Sogang University, Korea. Molecular weight distribution $\left(M_{W} / M_{n}\right)$ were determined by gel permeation chromatography (GPC) with a Waters instrument equipped with Styragel HR 3, 4 and 4E columns, M7725i manual injector, column heating chamber and 2010 Millennium data station. Dynamic light scattering measurements were performed using a UNIPHASE He-Ne laser operating at $632.8 \mathrm{~nm}$. The maximum operating power of the laser was $30 \mathrm{~mW}$. The detector optics employed optical fibers coupled to an ALV/SO-SIPD/DUAL detection unit, which employed an EMI PM$28 \mathrm{~B}$ power supply and ALV/PM-PD preamplifier/discriminator. The Signal analyzer was an ALV5000/E/WIN multiple tau digital correlator with 288 exponentially spaced channels. The scanning electron microscope (SEM) images were obtained from a FE-SEM (Hitachi S-4300) at an acceleration voltage of $15 \mathrm{kV}$. MALDI-TOF-MS was performed on a Perseptive Biosystems Voyager-DE STR using a 2,5-dihydroxy benzoic acid matrix. The transmission electron microscope (TEM) was performed at 120 $\mathrm{kV}$ using JEOL-JEM 2010. The steady-state fluorescence spectra were obtained from a Hitachi F-4500 fluorescence spectrophotometer. Preparative high performance liquid chromatography (HPLC) was performed at room temperature using a $20 \mathrm{~mm} \times 600 \mathrm{~mm}$ poly styrene column on a Japan Analytical Industry Model LC-908 recycling preparative HPLC system, equipped with UV detector 310 and RI detector RI-5. 
Synthesis. The synthetic procedures used in the preparation of amphiphilic rod-coil molecules $\mathbf{1}$ and $\mathbf{2}$ are described in Scheme 1.

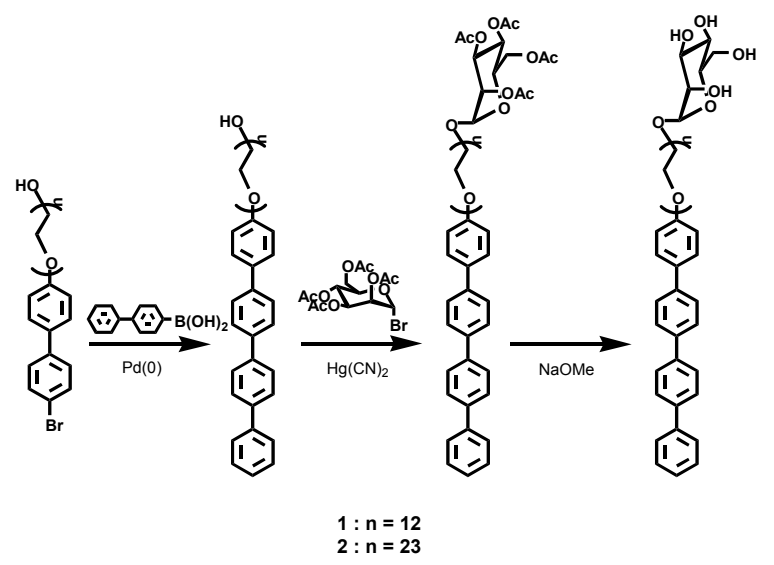

Scheme 1. Synthesis of molecules 1 and 2.

\section{Synthesis of 1 and 2.}

The synthesis of molecules $\mathbf{1}$ and $\mathbf{2}$ were synthesized using a similar procedure described previously ${ }^{1}$

1 : Yield 89\% ${ }^{1} \mathrm{H}-\mathrm{NMR}(250 \mathrm{MHz}, \mathrm{DMSO}, \mathrm{ppm}): \delta=7.79-7.64(\mathrm{~m}, 12 \mathrm{Ar}-H), \delta=7.48(\mathrm{t}, 2 \mathrm{Ar}-H, J=$ $15 \mathrm{~Hz}), \delta=7.40$ (d, $1 \mathrm{Ar}-H, J=15 \mathrm{~Hz}$ ), 7.06 (d, $2 \mathrm{Ar}-\mathrm{H}$, $o$ to $\left.\mathrm{CH}_{2} \mathrm{CH}_{2} \mathrm{O}, J=10 \mathrm{~Hz}\right), 4.70$ ( d, $1 \mathrm{H}, J=5 \mathrm{~Hz}$ ), $4.61(\mathrm{~s}, 1 \mathrm{H}), 4.57(\mathrm{~d}, 1 \mathrm{H}), 4.43(\mathrm{t}, 1 \mathrm{H}), \quad 4.12\left(\mathrm{t}, 2 \mathrm{H}, \mathrm{CH}_{2} \mathrm{CH}_{2} \mathrm{OAr}, J=5.1 \mathrm{~Hz}\right), 3.75-3.08(\mathrm{~m}$, overlapped with $\left.\mathrm{H}_{2} \mathrm{O}\right){ }^{13} \mathrm{C}-\mathrm{NMR}(250 \mathrm{MHz}$, DMSO, ppm) $: \delta=158.6,139.9,139.5,138.9,138.1,136.8,129.4,128.0$, 127.3, 127.0, 126.9, 115.3, 100.3, 74.3, 71.2, 70.1, 69.8, 69.3, 67.3, 66.0 Anal. Calcd for : $\mathrm{C}_{56} \mathrm{H}_{80} \mathrm{O}_{19}: \mathrm{C}$, 63.62; H, 7.63. Found C, 63.70; H, 7.54. MALDI-TOF-MS $m / z\left(\mathrm{M}+\mathrm{Na}^{+}\right)$1035.60, 1079.63, 1123.66 , 1137.72, 1211.77, 1255.81, 1299.85 Calcd. 1123.53.

2 : Yield $88 \%{ }^{1} \mathrm{H}-\mathrm{NMR}\left(500 \mathrm{MHz}, \mathrm{CDCl}_{3}, \mathrm{ppm}\right): \delta=7.86-7.66(\mathrm{~m}, 12 \mathrm{Ar}-H), \delta=7.46(\mathrm{t}, 2 \mathrm{Ar}-H, J=$ $15 \mathrm{~Hz}$ ), $\delta=7.26$ (d, $1 \mathrm{Ar}-H, J=15 \mathrm{~Hz}$ ), 7.03 (d, $2 \mathrm{Ar}-\mathrm{H}$, $o$ to $\mathrm{CH}_{2} \mathrm{CH}_{2} \mathrm{O}, J=10 \mathrm{~Hz}$ ), 4.86 ( s, $1 \mathrm{H}$ ), 4.37( s, $2 \mathrm{H}), 4.17(\mathrm{~m}, 3 \mathrm{H}), 3.93-3.49(\mathrm{~m}, 101 \mathrm{H}){ }^{13} \mathrm{C}-\mathrm{NMR}\left(500 \mathrm{MHz}, \mathrm{CDCl}_{3}, \mathrm{ppm}\right): \delta=158.56,140.76$, $140.16,139.84,139.71,139.00,134.75,133.39,128.91,128.08$, 127.60, 127.40, 127.14, 115.09, 100.25, 77.42, 77.16, 76.90, 72.73, 69.84, 67.62, 67.35, 66.76, 61.86 Anal. Calcd for : $\mathrm{C}_{70} \mathrm{H}_{108} \mathrm{O}_{26}: \mathrm{C}, 61.57 ; \mathrm{H}$, 7.97. Found C, 61.41; H, 7.94. MALDI-TOF-MS $m / z\left({\left.\mathrm{M}+\mathrm{Na}^{+}\right)}^{+} 1167.48,1211.50,1255.53,1299.56\right.$, 1343.58, 1387.61, 1431.63 1475.66, 1519.69. Calcd. 1343.71.

Synthesis. The synthetic procedures used in the preparation of amphiphilic rod-coil molecule 2a are described in Scheme 2. 


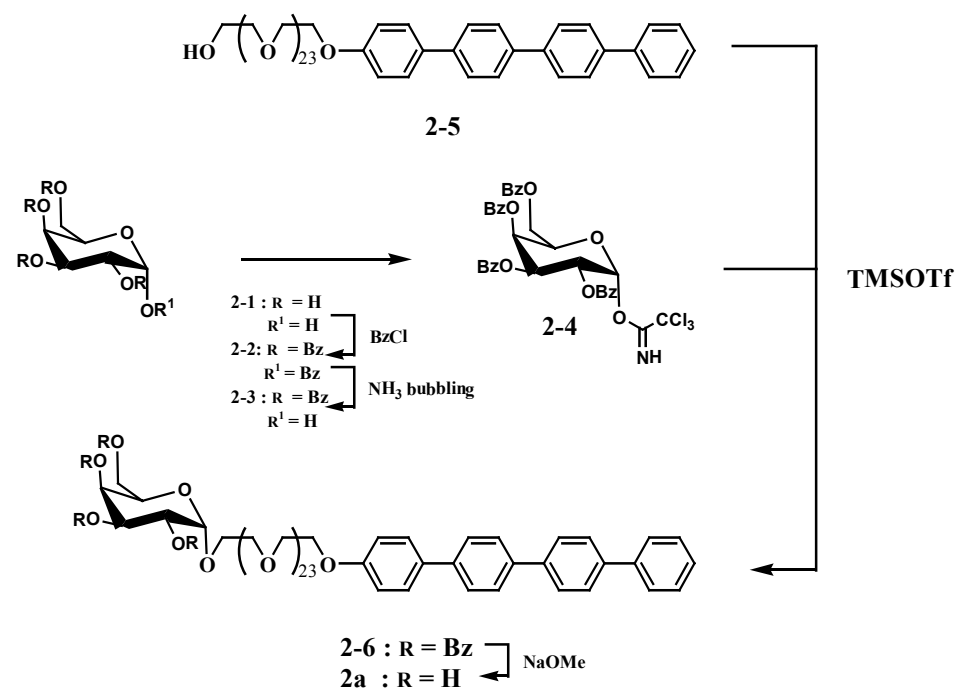

Scheme 2. Synthesis of molecule 2a.

\section{Synthesis of 2-4.}

The synthesis of molecules $\mathbf{2 - 2}, \mathbf{2 - 3}$ and 2-4 were synthesized using a similar procedure reported previously ${ }^{2}$

Synthesis of compound 2a : Compound 2-6 $(1.3 \mathrm{~g} 0.7 \mathrm{mmol})$ in the methanol $(15 \mathrm{ml})$ was treated with sodium methoxide $(20 \mathrm{mg})$ and stirred at room temperature for $0.5 \mathrm{~h}$. Then the solution was mixed with DOWEX MAC-3 ION exchange resin and stirred under nitrogen at room temperature for 30 minutes, filtered and concentrated to give a pure white solid product. yield $0.89 \mathrm{~g}(90 \%)$.; ${ }^{1} \mathrm{H}-\mathrm{NMR}(500 \mathrm{MHz}$, DMSO, ppm) : $\delta$ 7.87-7.44 (m, 12Ar- $H), \delta$ 7.13-7.1 (t, 2Ar- $H), \delta 4.92(\mathrm{~s}, 1 \mathrm{H}), \delta 4.64(\mathrm{~s}, 1 \mathrm{H}), \delta 4.44(\mathrm{~s}$, $1 \mathrm{H}), \delta 4.22(\mathrm{~s}, 1 \mathrm{H}) \delta 4.12(\mathrm{~s}, 1 \mathrm{H}), \delta 3.84(\mathrm{~s}, 1 \mathrm{H}), 3.59-3.23(\mathrm{~m}, 101 \mathrm{H}):{ }^{13} \mathrm{C}-\mathrm{NMR}(500 \mathrm{MHz}$, DMSO, ppm) $: \delta=156.4,139.6,130.0,128.6,128.2,127.9,127.5,115.9,104.5,76.1,74.4,73.3,70.7,69.1,68.6$, 68.2, 61.2, Anal. Calcd for : $\mathrm{C}_{70} \mathrm{H}_{108} \mathrm{O}_{26}$ : C, 61.57; H, 7.97. Found C, 61.52; H, 7.94. MALDI-TOF-MS $m / z\left(\mathrm{M}^{+\mathrm{Na}^{+}}\right) 1211.50,1255.53,1299.56,1343.58,1387.61,1431.63$ 1475.66, Calcd. 1343.71

Synthesis. The synthetic procedures used in the preparation of amphiphilic rod-coil molecule $\mathbf{3}$ are described in Scheme 3. 


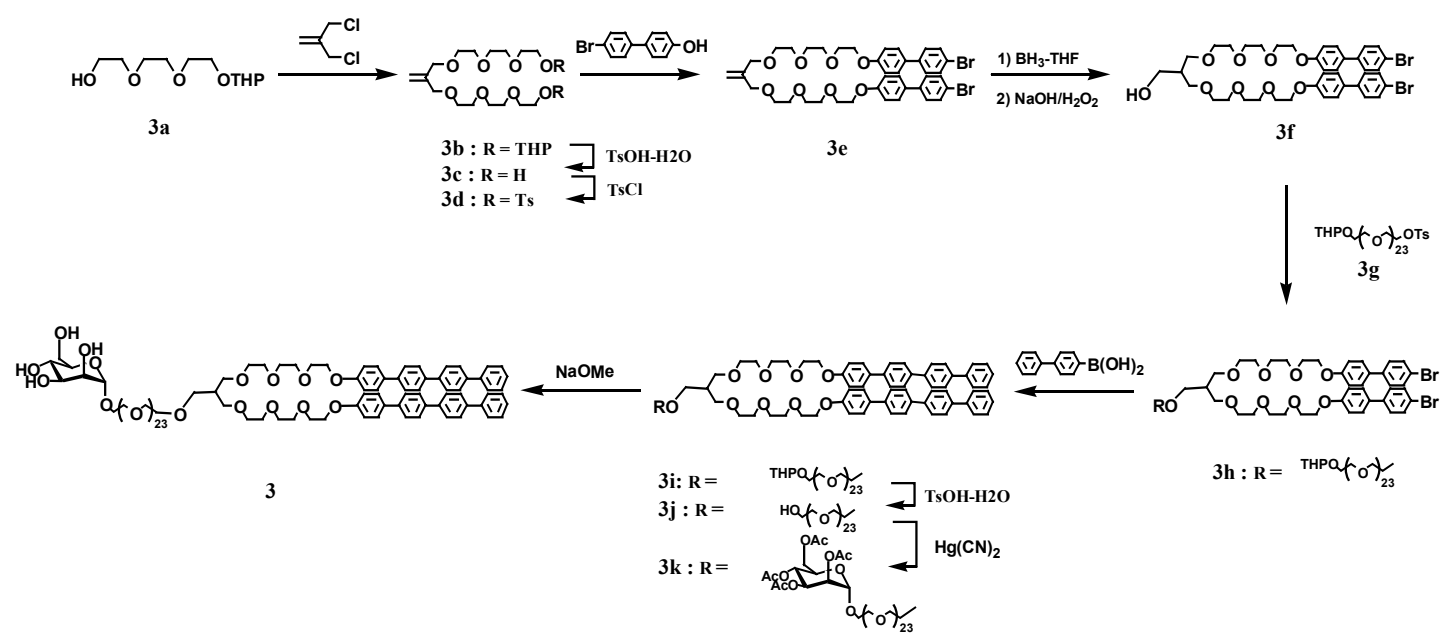

Scheme 3. Synthesis of molecule 3.

Synthesis of compound 3a : Tri(ethylene glycol) (10 g, $66.7 \mathrm{mmol}, 1 \mathrm{eq})$ and pyridinium $p$-toluene sulfonic acid (1.8 g, $6.67 \mathrm{mmol}, 0.1 \mathrm{eq})$ were added to methylene chloride $(200 \mathrm{ml})$. The reaction mixture was cooled to $0{ }^{\circ} \mathrm{C}$. Within $10 \mathrm{~min}, 3$, 4-dihydro-2H-pyran $(8.5 \mathrm{~g}, 100 \mathrm{mmol}, 1.5 \mathrm{eq})$ was added to the mixture. The reaction mixture was stirred at $25{ }^{\circ} \mathrm{C}$ under nitrogen for $5 \mathrm{hrs}$. Then the reaction mixture was washed with saturated aqueous sodium bicarbonate and dried over anhydrous magnesium sulfate. Solvent was evaporated under reduced pressure. The crude product was purified by column chromatography (silica gel) using ethyl acetate : methanol $(10: 1 \mathrm{v} / \mathrm{v})$ as eluent to yield $8 \mathrm{~g}(51 \%)$ of a colorless oil. : ${ }^{1} \mathrm{H}-$ NMR $\left(250 \mathrm{MHz}, \mathrm{CDCl}_{3}, \mathrm{ppm}\right) \delta 4.62-4.60\left(\mathrm{t}, 1 \mathrm{H}, \mathrm{OCH}_{2}\left(\mathrm{CH}_{2}\right)_{3} \mathrm{CH}\right.$ of the THP group), $\delta 3.88-3.82$ (m, $2 \mathrm{H}, \mathrm{OCH}_{2}\left(\mathrm{CH}_{2}\right)_{3} \mathrm{CH}$ of the THP group), $\delta 3.70-3.65\left(\mathrm{~m}, 12 \mathrm{H}, \mathrm{CH}\right.$ and $\left.\mathrm{OCH}_{2}\right), \delta 1.61-1.49(\mathrm{~m}, 6 \mathrm{H}$, $\mathrm{OCH}_{2}\left(\mathrm{CH}_{2}\right)_{3} \mathrm{CH}$ of the THP group).

Synthesis of compound 3b : Dried NaH (1.63 g, $68.3 \mathrm{mmol}, 2 \mathrm{eq})$ and methallyl dichloride (1.7 g, 13.6 mmol, 0.4 eq) were dissolved in freshly distilled dry THF $(100 \mathrm{ml})$ under nitrogen. Compound 3a $(8 \mathrm{~g}$, $34.1 \mathrm{mmol}, 1 \mathrm{eq})$ was added into the mixture dropwisely at room temperature. The mixture was stirred at room temperature for $\sim 15 \mathrm{~min}$ and then reflux at $\sim 65{ }^{\circ} \mathrm{C}$ for $12 \mathrm{hrs}$. After cooling to room temperature, the reaction mixture was quenched with water and extracted with methylene chloride. The organic layer was then dried over anhydrous $\mathrm{MgSO}_{4}$ and the solvent was then removed in a rotatory evaporator. Purification of the residue by flash column chromatography on silica gel in a mixture eluent of ethyl acetate and methanol $(19: 1 \mathrm{v} / \mathrm{v})$ as eluent to yield $14.4 \mathrm{~g}(81 \%)$ of a colorless liquid; ${ }^{1} \mathrm{H}-\mathrm{NMR}(250$ $\mathrm{MHz}, \mathrm{CDCl}_{3}, \delta$, ppm) $\delta 5.0\left(\mathrm{~s}, 2 \mathrm{H}, \mathrm{CH}_{2} \mathrm{C}\left(\mathrm{CH}_{2}\right)_{2}\right), \delta 4.48-3.86\left(\mathrm{t}, 2 \mathrm{H}, \mathrm{OCH}_{2}\left(\mathrm{CH}_{2}\right)_{3} \mathrm{CH}\right.$ of the THP group), $\delta 3.73\left(\mathrm{~s}, 4 \mathrm{H}, \mathrm{CH}_{2} \mathrm{C}\left(\mathrm{CH}_{2}\right)_{2}\right), \delta 3.73-3.66\left(\mathrm{~m}, 4 \mathrm{H}, \mathrm{OCH}_{2}\left(\mathrm{CH}_{2}\right)_{3} \mathrm{CH}\right.$ of the THP group), $\delta 3.53-3.35(\mathrm{~m}, 24 \mathrm{H}$, $\left.\left(\mathrm{OCH}_{2} \mathrm{CH}_{2}\right)_{3}\right), \delta 1.55-1.37\left(\mathrm{~m}, 12 \mathrm{H}, \mathrm{OCH}_{2}\left(\mathrm{CH}_{2}\right)_{3} \mathrm{CH}\right.$ of the THP group). 
Synthesis of compound 3d : The compound 3b (14.4 g $27.6 \mathrm{mmol}, 1 \mathrm{eq})$ was dissolved in $200 \mathrm{ml}$ of methanol at $0{ }^{\circ} \mathrm{C}$ and was stirred for $15 \mathrm{~min}, \mathrm{TsOH} \cdot \mathrm{H}_{2} \mathrm{O}(520 \mathrm{mg}, 2.76 \mathrm{mmol}, 0.1 \mathrm{eq})$ was added. The mixture was stirred at room temperature under nitrogen for $4 \mathrm{hrs}$. This reaction gave complete removal of the THP group. Sodium bicarbonate was then added to quench the reaction. The solution was extracted with ethyl acetate and drying of the collected organic layers with anhydrous magnesium sulfate. And evaporation of the solvent yielded a mixture. Then the compound $\mathbf{3 c}$ was given by deprotecting of compound $\mathbf{3 b}$ without further purification. The compound $\mathbf{3} \mathbf{c}$ was dissolved in dried methylene chloride, and after cooling of the solution in ice for $15 \mathrm{~min}, p$-toluene-sulfonyl chloride (15.8 $\mathrm{g} 82.9 \mathrm{mmol}, 3 \mathrm{eq})$ was added. Then pyridine was added under nitrogen. The reaction was stirred at room temperature under nitrogen for $12 \mathrm{hrs}$. The solution was quenched with $1 \mathrm{M} \mathrm{HCl}$ and extracted with methylene chloride. The organic layer was washed with water, dried over anhydrous magnesium sulfate. The solvent was removed in a rotatory evaporator. The crude product was purified by column chromatography (silica gel) using methylene chloride : methanol $(10: 1 \mathrm{v} / \mathrm{v})$ as eluent to yield $12.6 \mathrm{~g}(69 \%)$ of a white solid : ${ }^{1} \mathrm{H}-$ NMR (250 MHz, $\left.\mathrm{CDCl}_{3}, \delta, \mathrm{ppm}\right) \delta$ 7.8-7.76 (d, 4H, 2Ar- $H ; m$ to $\left.\mathrm{SO}_{3}\right), \delta 7.33$ (d, 4H, $2 \mathrm{Ar}-H ; o$ to $\left.\mathrm{SO}_{3}\right), \delta$ $5.1\left(\mathrm{~s}, 2 \mathrm{H}, \mathrm{CH}_{2} \mathrm{C}\left(\mathrm{CH}_{2}\right)_{2}\right), \delta 4.1\left(\mathrm{t}, 4 \mathrm{H}, \mathrm{CH}_{2}-\mathrm{OTs}\right), \delta 3.9\left(\mathrm{~s}, 4 \mathrm{H}, \mathrm{CH}_{2} \mathrm{C}\left(\mathrm{CH}_{2}\right)_{2}\right), \delta 3.6-3.5(\mathrm{~m}, 24 \mathrm{H}$, $\left.\left(\mathrm{OCH}_{2} \mathrm{CH}_{2}\right)_{3}\right), \delta 2.4\left(\mathrm{~s}, 3 \mathrm{H}, \mathrm{Ar}-\mathrm{CH}_{3}\right)$.

Synthesis of compound 3e : The compound $3 \mathbf{d}(5 \mathrm{~g}, 7.57 \mathrm{mmol}, 1 \mathrm{eq})$ and excess $\mathrm{K}_{2} \mathrm{CO}_{3}$ were dissolved in $150 \mathrm{ml}$ of anhydrous acetonitrile. The mixture was heated at reflux for $12 \mathrm{hrs}$. The solvent was removed in a rotary evaporator. The resulting residue was poured into water and extracted with methylene chloride. The methylene chloride solution was washed with water, dried over anhydrous magnesium sulfate, and then filtered. Solvent was removed in a rotatory evaporator, and the crude product was then purified by column chromatography (silicagel) using methylene chloride : methanol $(20: 1 \mathrm{v} / \mathrm{v})$ to yield $3.35 \mathrm{~g}(56 \%)$ of a white solid : ${ }^{1} \mathrm{H}-\mathrm{NMR}\left(250 \mathrm{MHz}, \mathrm{CDCl}_{3}, \delta, \mathrm{ppm}\right) \delta$ 7.4-7.2 (m, 12H, Ar-6H), $\delta 6.94-$ 6.91 (d, $4 \mathrm{H}, \mathrm{Ar}-2 \mathrm{H}$, o to $\mathrm{Ar}-\mathrm{Br}$ ), $\delta 5.17$ (s, $\left.\left.2 \mathrm{H}, \mathrm{CH}_{2} \mathrm{C}_{\left(\mathrm{CH}_{2}\right)}\right)_{2}\right), \delta$ 4.1-4.0 (t, $2 \mathrm{H}, \mathrm{OCH}_{2} \mathrm{CH}_{2} \mathrm{O}-\mathrm{Ar}$ ), $\delta 3.8$ (s, $\left.4 \mathrm{H}, \mathrm{CH}_{2} \mathrm{C}\left(\mathrm{CH}_{2}\right)_{2}\right) \delta 3.69-3.56\left(\mathrm{~m}, 20 \mathrm{H},\left(\mathrm{OCH}_{2} \mathrm{CH}_{2}\right)_{2} \mathrm{OCH}_{2}\right)$.

Synthesis of compound $3 \mathbf{f}$ : Compound $3 \mathbf{e}(3.35 \mathrm{~g}, 4.1 \mathrm{mmol}, 1 \mathrm{eq})$ was dissolved in freshly distilled dry THF $(100 \mathrm{ml})$ under nitrogen $n_{2}$ and cooled to $0{ }^{\circ} \mathrm{C}$ in a ice bath. To this mixture, $1 \mathrm{M} \mathrm{BH}_{3}$ in THF $(16.5 \mathrm{ml}$, $16.4 \mathrm{mmol}, 4 \mathrm{eq}$ ) was added slowly and the reaction mixture was then allowed to stir at $0{ }^{\circ} \mathrm{C}$ for $2 \mathrm{hrs}$. The reaction mixture was then quenched with $3 \mathrm{M}$ aqueous $\mathrm{NaOH}$ solution $(20 \mathrm{ml})$ and allowed to stir for $15 \mathrm{~min}$. This was followed by addition of $30 \% \mathrm{H}_{2} \mathrm{O}_{2}$ aqueous solution $(20 \mathrm{ml})$ and the mixture was stirred at room temperature for $1 \mathrm{hr}$. The reaction mixture was saturated with $\mathrm{K}_{2} \mathrm{CO}_{3}$ and extracted with methylene chloride. The organic layer was dried over anhydrous $\mathrm{MgSO}_{4}$ and the solvent was removed in a rotatory evaporator. Purification of the residue by flash column chromatography (silica gel) in a mixture eluent of methylene chloride : methanol (19 : $1 \mathrm{v} / \mathrm{v})$ yielded $2.84 \mathrm{~g}(84 \%)$ of a white solid : ${ }^{1} \mathrm{H}-\mathrm{NMR}$ 
(250 MHz, $\mathrm{CDCl}_{3}, \delta$, ppm) $\delta$ 7.52-7.37 (m, 12H, Ar-6H), $\delta$ 6.98-6.95 (d, 4H, Ar-2H, o to Ar-Br), $\delta$ 4.15$4.13\left(\mathrm{t}, 2 \mathrm{H}, \mathrm{OCH}_{2} \mathrm{CH}_{2} \mathrm{O}-\mathrm{Ar}\right), \delta 3.88-3.86\left(\mathrm{t}, 4 \mathrm{H}, \mathrm{HOCH}_{2} \mathrm{CH}\left(\mathrm{CH}_{2}\right)_{2}\right) \delta$ 3.72-3.55 (m, 20H, $\left(\mathrm{OCH}_{2} \mathrm{CH}_{2}\right)$ $\left.{ }_{2} \mathrm{OCH}_{2}\right), \delta 2.07\left(\mathrm{~m}, 1 \mathrm{H}, \mathrm{CH}\left(\mathrm{OCH}_{2}\right)_{2}\right)$.

Synthesis of compound $3 \mathrm{~h}$ : Compound $\mathbf{3 g}$ was synthesized by using similar procedure described for compound 3a and 3d. Compound $3 \mathbf{f}$ (2.84 g, $3.4 \mathrm{mmol}, 1 \mathrm{eq})$ and $\mathbf{3 g}$ (4.6 g, $4.1 \mathrm{mmol}, 1.2 \mathrm{eq})$ were dissolved in $500 \mathrm{ml}$ of dry THF. Sodium hydride $(80 \mathrm{mg}, 3.4 \mathrm{mmol}, 1 \mathrm{eq}$ ) was added, and the mixture was then heated with reflux for $12 \mathrm{hrs}$. After cooling to room temperature, the reaction mixture was quenched with water. THF was removed in a rotatory evaporator. After extraction with methylene chloride, the organic layer was dried over anhydrous magnesium sulfate and the solvent was removed in a rotatory evaporator. Purification of the residue by flash column chromatography on silica gel in a mixture eluent of methylene chloride : methanol (30:1 to $20: 1 \mathrm{v} / \mathrm{v})$ yielded $4.96 \mathrm{~g}(81 \%)$ of a colorless waxy liquid. ${ }^{1} \mathrm{H}-\mathrm{NMR}\left(250 \mathrm{MHz}, \mathrm{CDCl}_{3}, \delta, \mathrm{ppm}\right) \delta$ 7.52-7.37 (m, 12H, Ar-6H), $\delta$ 6.98-6.95 (d, 4H, Ar-2H, o to Ar-Br), $\delta$ 4.15-4.13 (t, 2H, $\left.\mathrm{OCH}_{2} \mathrm{CH}_{2} \mathrm{O}-\mathrm{Ar}\right), \delta 3.88-3.86\left(\mathrm{t}, 4 \mathrm{H}, \mathrm{OCH}_{2} \mathrm{CH}\left(\mathrm{CH}_{2}\right)_{2}\right) \delta 3.72-3.46\left(\mathrm{~m}, 100 \mathrm{H}, \mathrm{CH}\left(\mathrm{CH}_{2}\right.\right.$ $\left.\left.\left(\mathrm{OCH}_{2} \mathrm{CH}_{2}\right)_{3} \mathrm{O}\right)_{2}\right)$ and $\left.\mathrm{THP}\left(\mathrm{OCH}_{2} \mathrm{CH}_{2}\right)_{20} \mathrm{O}\right), \delta 2.07\left(\mathrm{~m}, 1 \mathrm{H}, \mathrm{CH}\left(\mathrm{OCH}_{2}\right)_{2}, \delta 1.55-1.37(\mathrm{~m}, 12 \mathrm{H}\right.$, $\mathrm{OCH}_{2}\left(\mathrm{CH}_{2}\right)_{3} \mathrm{CH}$ of the THP group).

Synthesis of compound 3i : Compound 3h (4.96 g, $2.75 \mathrm{mmol}, 1 \mathrm{eq})$ and 4-biphenyl boronic acid (1.36 g, $6.98 \mathrm{mmol}, 2.5 \mathrm{eq}$ ) were dissolved in $100 \mathrm{ml}$ of degassed tetrahydrofuran and $70 \mathrm{ml}$ of degassed $2 \mathrm{M}$ aqueous sodium carbonate. Then tetrakis(triphenylphosphine)palladium(0) (31 mg, $0.027 \mathrm{mmol}, 0.01 \mathrm{eq})$ was added into the solution. The mixture was heated at reflux for $48 \mathrm{hrs}$ with vigorous stirring under nitrogen. Cooled to room temperature, the layers were separated, and the aqueous layer was then washed twice with methylene chloride. The combined organic layer was dried over anhydrous magnesium sulfate and filtered. The solvent was removed in a rotary evaporator, and the crude product was purified by column chromatography (silica gel) using methlylene chloride : methanol (30:1 to $20: 1 \mathrm{v} / \mathrm{v})$ as eluent to yield $3.44 \mathrm{~g}(62.3 \%)$ : ${ }^{1} \mathrm{H}-\mathrm{NMR}\left(250 \mathrm{MHz}, \mathrm{CDCl}_{3}, \delta\right.$, ppm) $\delta$ 7.69-7.35 (m, 30H, Ar-6H), $\delta$ 7.01-6.98 (d, $4 \mathrm{H}, \mathrm{Ar}-2 \mathrm{H}, \mathrm{o}$ to Ar), $\delta 4.19-4.17$ (t, 8H, $\mathrm{OCH}_{2} \mathrm{CH}_{2} \mathrm{O}-\mathrm{Ar}$ and $\left.\left.4 \mathrm{H}, \mathrm{OCH}_{2} \mathrm{CH}\left(\mathrm{CH}_{2}\right)_{2}\right)\right), \delta 3.72-3.46(\mathrm{~m}, 100 \mathrm{H}$, $\left.\mathrm{CH}\left(\mathrm{CH}_{2}\left(\mathrm{OCH}_{2} \mathrm{CH}_{2}\right)_{3} \mathrm{O}\right)_{2}\right)$ and $\left.\mathrm{THP}\left(\mathrm{OCH}_{2} \mathrm{CH}_{2}\right)_{20} \mathrm{O}\right), \delta 2.07\left(\mathrm{~m}, 1 \mathrm{H}, \mathrm{CH}\left(\mathrm{OCH}_{2}\right)_{2}, \delta 1.55-1.37(\mathrm{~m}, 6 \mathrm{H}\right.$, $\mathrm{OCH}_{2}\left(\mathrm{CH}_{2}\right)_{3} \mathrm{CH}$ of the THP group).

Synthesis of compound $\mathbf{3} \mathbf{j}$ : Compound $\mathbf{3 j}$ was synthesized by using similar procedure described for compound 3c. The mixture was purified by flash column chromatography (silica gel) using methylene chloride : methanol $(10: 1 \mathrm{v} / \mathrm{v})$ as eluent to yield 3.1g (94.1\%) of a white solid : ${ }^{1} \mathrm{H}-\mathrm{NMR}(250 \mathrm{MHz}$, $\left.\mathrm{CDCl}_{3}, \delta, \mathrm{ppm}\right) \delta$ 7.69-7.35 (m, 30H, Ar-6H), $\delta$ 7.01-6.98 (d, 4H, Ar-2H, $o$ to Ar), $\delta$ 4.19-4.17 (t, $8 \mathrm{H}$, $\mathrm{OCH}_{2} \mathrm{CH}_{2} \mathrm{O}-\mathrm{Ar}$ and $\left.\left.4 \mathrm{H}, \mathrm{OCH}_{2} \mathrm{CH}\left(\mathrm{CH}_{2}\right)_{2}\right)\right), \delta 3.72-3.46\left(\mathrm{~m}, 96 \mathrm{H}, \mathrm{CH}\left(\mathrm{CH}_{2}\left(\mathrm{OCH}_{2} \mathrm{CH}_{2}\right)_{3} \mathrm{O}\right)_{2}\right), \delta 2.07(\mathrm{~m}$, $\left.1 \mathrm{H}, \mathrm{CH}\left(\mathrm{OCH}_{2}\right)_{2}\right)$. 
Synthesis of compound 3k : To a solution of 1-bromo 2,3,4,6-tetra- $O$-acetyl-mannopyranoside (1.3 g $3.33 \mathrm{mmol}, 2 \mathrm{eq})$ in $100 \mathrm{ml}$ of acetonitrile was added compound $\mathbf{3 j} \mathbf{j}(3.1 \mathrm{~g}, 1.6 \mathrm{mmol}, 1 \mathrm{eq})$ and mercury(II) cyanide ( $400 \mathrm{mg}, 1.6 \mathrm{mmol}, 1 \mathrm{eq}$ ). The mixture was stirred for $4 \mathrm{hrs}$ at room temperature and then filtered. The resulting residue was dissolved chloroform $(200 \mathrm{ml})$ and washed with aqueous $\mathrm{NaCl}$ solution. The organic layer was dried over anhydrous magnesium sulfate and filtered and concentrated. The crude product was purified by a flash column chromatography (silica gel) methylene chloride : methanol $(20: 1 \mathrm{v} / \mathrm{v}))$ to yield $1.9 \mathrm{~g}(53 \%)$ of a white solid ; ${ }^{1} \mathrm{H}-\mathrm{NMR}\left(250 \mathrm{MHz}, \mathrm{CDCl}_{3}, \delta, \mathrm{ppm}\right) \delta 7.69$ 7.35 (m, 30H, Ar-6H), $\delta$ 7.01-6.98 (d, 4H, Ar-2H, o to Ar), $\delta$ 5.22-5.12 (m, 3H, H-2, H-3, H-4), 4.78 (d, $1 \mathrm{H}, H-1), \delta$ 4.19-4.17 (t, 8H, $\mathrm{OCH}_{2} \mathrm{CH}_{2} \mathrm{O}-\mathrm{Ar}$ and $\left.\left.4 \mathrm{H}, \mathrm{OCH}_{2} \mathrm{CH}\left(\mathrm{CH}_{2}\right)_{2}\right)\right), \delta 4.78(\mathrm{~d}, 1 \mathrm{H}, H-1), \delta$ 4.03-3.95 (m, 2H, H-6b, H-5), $3.84\left(\mathrm{t}, 2 \mathrm{H}, \mathrm{CH}_{2} \mathrm{OH}\right), \delta 3.72-3.46\left(\mathrm{~m}, 96 \mathrm{H}, \mathrm{CH}\left(\mathrm{CH}_{2}\left(\mathrm{OCH}_{2} \mathrm{CH}_{2}\right)_{3} \mathrm{O}\right)_{2}\right) \delta 2.052 .00$ $1.941 .91\left(\mathrm{~s}, 12 \mathrm{H}, \mathrm{O}=\mathrm{CH}_{3}\right)$.

Synthesis of compound 3 : Compound 3k $(1.9 \mathrm{~g} 0.88 \mathrm{mmol})$ in $25 \mathrm{ml}$ of methanol $(25 \mathrm{ml})$ was treated with sodium methoxide $(10 \mathrm{mg})$ and stirred at room temperature for $0.5 \mathrm{~h}$. Then the solution was mixed with DOWEX MAC-3 ION exchange resin and stirred at room temperature $0.5 \mathrm{~h}$, filtered and concentrated to give a pure white solid product. yield 1.11g (93.2 \%).; ${ }^{1} \mathrm{H}-\mathrm{NMR}\left(250 \mathrm{MHz}, \mathrm{CDCl}_{3}, \delta\right.$, ppm) $\delta$ 7.69-7.35 (m, 30H, Ar-6H), $\delta$ 7.01-6.98 (d, 4H, Ar-2H, o to Ar), 4.72 ( d, $1 \mathrm{H}, H-1), 4.68,4.65$, 4.53, 4.42 (d, $4 \mathrm{H}, H-2, H-3, H-4, H-5$ ), $\delta 4.19-4.17$ (t, 8H, $\mathrm{OCH}_{2} \mathrm{CH}_{2} \mathrm{O}-\mathrm{Ar}$ and $\left.4 \mathrm{H}, \mathrm{OCH}_{2} \mathrm{CH}\left(\mathrm{CH}_{2}\right)_{2}\right)$ ), $\delta$ $3.84\left(\mathrm{t}, 2 \mathrm{H}, \mathrm{CH}_{2} \mathrm{OH}\right), \delta 3.72-3.46\left(\mathrm{~m}, 96 \mathrm{H}, \mathrm{CH}\left(\mathrm{CH}_{2}\left(\mathrm{OCH}_{2} \mathrm{CH}_{2}\right)_{3} \mathrm{O}\right)_{2}\right)$ ) , 3.65(d, $\left.2 \mathrm{H}, H-6\right), 3.60-3.22(\mathrm{~m}$, overlapped with $\left.\mathrm{H}_{2} \mathrm{O}\right):{ }^{13} \mathrm{C}-\mathrm{NMR}(250 \mathrm{MHz}$, DMSO, ppm) $: \delta=158.6,140.8,140.2,139.7,139.0,133.4$, 128.9, 128.1, 127.6, 115.1, 100.2, 77.4, 76.9, 71.7, 70.6, 69.9, 69.7, 68.7, 67.6, 66.8. Anal. Calcd for : $\mathrm{C}_{110} \mathrm{H}_{156} \mathrm{O}_{34}: \mathrm{C}, 62.67$; $\mathrm{H} 7.68$. Found C, 62.52; H, 7.59.

\section{Determination of critical micellar concentration $(\mathbf{c m c})^{6}$}

The $1 \mathrm{ml}$ of prepared Nile Red Solution $\left(1 \times 10^{-1} \mathrm{~g} / \mathrm{L}\right.$ in methylene chloride) was added to aqueous 1-3 solution with different concentrations (from 0.5 to $0.0001 \mathrm{~g} / \mathrm{L}$ ) and sonicated for a few hours at room temperature to allow for reaching equilibrium. The methylene chloride was removed via evaporation. After being filtered through $0.45 \mu \mathrm{m}$ hydrophilic filter (PVDF membrane filter), Uv/vis spectroscopy measurements were performed with the solutions with different 1-3 concentrations at fixed Nile Red content. The cmc of the molecules were determined by plotting the absorption intensity of Nile Red in an aqueous phase against amphiphile concentration. The low concentration range, a negligible absortion peak was detected. However, above a certain concentration, the absorption intensity exhibited a substantial increase, indicating that dye molecules are encapsulated into the hydrophobic core region upon aggregation. Therefore, the critical micellar concentrations were determined from the cross-over point at the low concentration range. 
Binding of compound 1 to $\boldsymbol{E}$. coli type 1 pili. $^{3}$ : The E. coli K-12 stains ORN 178 and ORN 208 (kindly provided by Prof. P.E. Orndorff) were grown in LB medium at $37{ }^{\circ} \mathrm{C}$ to an optical density of 0.7 at 600 $\mathrm{nm}$ (approximately $10^{9}$ cells per $\mathrm{ml}$ ). Bacteria from $200 \mu \mathrm{l}$ culture was precipitated by centrifugation at $3000 \mathrm{rpm}$ for $5 \mathrm{~min}$, redissolved in $200 \mu \mathrm{l}$ binding buffer (water) and followed by adding $10 \mu \mathrm{l}$ nanoparticle solution. The resulting bacteria and nanoparticle mixtures were incubated at temperatures $\left(37^{\circ} \mathrm{C}\right)$ with mild shaking for $30 \mathrm{~min}$. After washing three times with binding buffer, bacteria were redissolved in 10-20 $\mu 1$ binding buffers.

Transmission Electron Microscopy (TEM) measurement : Approximately each sample of $5 \mu$ was placed onto a carbon-coated grid, and the suspension was allowed to settle for 1 to 2 min before excess liquid was removed with a paper wick. A drop of $1 \%$ phosphotungastic acid was then used to negatively stain the sample for 40 seconds. For study of structure of 1-3 in aqueous solution, a drop of aqueous solution of molecules 1-3 (0.05 wt \%) was placed on a carbon-coated copper grid, and dried at room temperature. The stained cells (1-2) were examined by JEOL-JEM 2010 TEM. Sample (3) was stained by depositing a drop of $2 \mathrm{wt} \%$ uranyl acetate aqueous solution onto the surface of the sample-loaded grid.

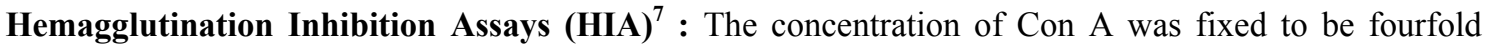
minimum concentration required for hemagglutination of erythrocyte, Twenty $\mu 1$ of a $3 \%$ erythrocyte (Rabbit blood) suspension in a $0.1 \mathrm{M}$ phosphate buffer (PBS, $\mathrm{pH} 7.4$ ) containing $0.1 \mathrm{mM} \mathrm{CaCl}_{2}$ and 0.1 $\mathrm{mM} \mathrm{MgCl}_{2}$ was pipetted into each well of the twofold dilution series of Con $\mathrm{A}(20 \mu \mathrm{l})$ in 96-holes microtiter plate, and incubated at $25^{\circ} \mathrm{C}$ for $1 \mathrm{~h}$. The minimum concentration of Con A was determined, and its fourfold concentration was used for the following Con A-induced hemaggultination assay. An aliquot $(20 \mu \mathrm{l})$ of Con $\mathrm{A}$ in the buffer was added to each hole of 96-holes microtiter plates. The mannose conjugates dissolved in the buffer with various concentrations were added to the each hole $(20 \mu \mathrm{l})$ and incubated at $25{ }^{\circ} \mathrm{C}$ for $2 \mathrm{hrs}$. Then, $3 \%$ erythrocyte suspension $(40 \mu \mathrm{l})$ was added to the holes and incubated at $25{ }^{\circ} \mathrm{C}$ for $1 \mathrm{~h}$. Agglutination of erythrocytes was observed and determined by visual inspection. At the concentrations used, no precipitation of Con A was observed. All the experiments were carried out triplicate.

Dynamic Laser Light Scattering : The DLS were performed with the aqueous solutions of 1, 2 and 3 (2 $\left.\times 10^{-4} \mathrm{~g} / \mathrm{ml}\right)$ over a scattering angle range of $30^{\circ}$ to $140^{\circ}$ at $25^{\circ} \mathrm{C}$. The hydrodynamic radius $\left(R_{\mathrm{H}}\right)$ and diffusion coefficient were determined from the DLS autocorrelation functions by cumulant analysis using the software provided by the manufacturer. 


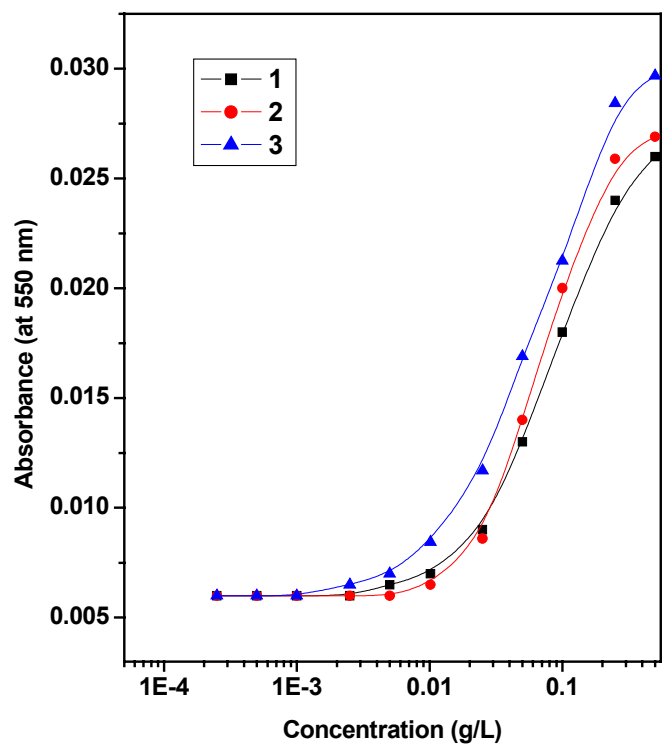

Figure S1. Absorbance intensity of Nile Red at $550 \mathrm{~nm}$ as a function of the concentration of 1-3 solutions in water.

\section{References}

1. Kim, B,-S.; Yang, W,-Y.; Ryu, J.-H.; Yoo, Y,-S.; Lee. M. Chem. commun., 2005, 2035.

2. Mbadugha, B. N. A.; Menger, F. M. Org. Lett., 2003, 5, 4041

3. Lin, C.-C.; Yeh, Y.-C.; Yang, C.-Y.; Chen, C.-L.; Chen, G.-F.; Chen, C.-C.; Wu, Y.-C. J. Am. Chem. Soc. 2002, 124, 3508.

4. Ryu, J.-H.; Oh, N.-K.; Zin, W. -C.; Lee, M. J. Am. Chem. Soc. 2004, 126, 3551.

5. Yoo, Y.-S.; Choi, J.-H.; Song, J.-H.; Oh, N.-K.; Zin, W.-C.; Park, S.; Chang, T.; Lee, M. J. Am. Chem. Soc. 2004, 126, 6294.

6. Jang, C.-J.; Ryu, J.-H.; Lee, J.-D.; Sohn, D; Lee, M. Chem. Mater. 2004, 16, 4226.

7. Ooya, Y.; Eguchi, M.; Yui, N. J. Am. Chem. Soc. 2003, 125, 13016 